\title{
Relationship between obesity and depression, anxiety and psychological distress among Iranian health-care staff
}

Motahar Heidari-Beni, ${ }^{1}$ Fatemeh Azizi-Soleiman, ${ }^{2}$ Hamid Afshar, ${ }^{3}$ Hossein Khosravi-Boroujeni, ${ }^{4}$ Ammar Hassanzadeh Keshteli, ${ }^{5,6}$ Ahmad Esmaillzadeh ${ }^{7}$ and Peyman Adibi ${ }^{6}$

${ }^{1}$ Department of Nutrition, Child Growth and Development Research Center, Research Institute for Primordial Prevention of Non-Communicable Disease, Isfahan University of Medical Sciences, Isfahan, Islamic Republic of Iran. ${ }^{2}$ School of Health, Arak University of Medical Sciences, Arak, Islamic Republic of Iran. ${ }^{3}$ Psychosomatic Research Center, Department of Psychiatry, Isfahan University of Medical Sciences, Isfahan, Islamic Republic of Iran. ${ }^{4}$ Menzies Health Institute Queensland, and School of Medicine, Griffith University, Gold Coast Campus, QLD, Australia. ${ }^{5}$ Department of Medicine, University of Alberta, Edmonton, Alberta, Canada. ${ }^{6}$ Integrative Functional Gastroenterology Research Center, Isfahan University of Medical Sciences, Isfahan, Islamic Republic of Iran. ${ }^{7}$ Department of Community Nutrition, School of Nutritional Sciences and Dietetics, Tehran University of Medical Sciences, Tehran, Islamic Republic of Iran (Correspondence to: Ahmad Esmaillzadeh: a-esmaillzadeh@sina.tums.ac.ir).

\begin{abstract}
Background: Psychological-related disorders such as obesity are a key contributor to morbidity and mortality.

Aims: To assess the association between general and abdominal obesity with depression and anxiety among Iranian health-care staff.

Methods: This cross-sectional study was conducted under the framework of the Study on the Epidemiology of Psychological Alimentary Health and Nutrition. A total of 4361 Iranian health-care staff were analysed for general obesity and 3213 for central obesity. Overweight and obesity was defined as body mass index $25.0-29.9$ and $\geq 30.0 \mathrm{~kg} / \mathrm{m}^{2}$, respectively. Abdominal obesity was defined as waist circumference (WC) $\geq 88 \mathrm{~cm}$ for females and $\geq 102 \mathrm{~cm}$ for males. The Iranian validated versions of the Hospital Anxiety and Depression Scale and the General Health Questionnaire were used to assess depression and anxiety.

Results: Stratified analysis by sex revealed no significant relationship between general obesity, depression and anxiety among males. However, we found an inverse association between abdominal obesity (WC $>102 \mathrm{~cm}$ ) and severe depression among males. In females, abdominal obesity was significantly associated with anxiety, before and after taking confounders into account. No significant association was seen between abdominal obesity and psychological distress in either sex after controlling for potential confounders.
\end{abstract}

Conclusions: Abdominal obesity was associated with anxiety in Iranian adult females but not in males. Further studies, particularly prospective research, are required to confirm these findings.

Keywords: obesity, abdominal obesity, psychological health, depression, anxiety

Citation: Heidari-Beni M; Azizi-Soleiman F; Afshar H; Khosravi-Boroujeni H; Hassanzadeh Keshteli A; Esmaillzadeh A. et al. Relationship between obesity and depression, anxiety and psychological distress among Iranian health-care staff. East Mediterr Health J. 2021;27(4):326-335. https://doi.org/10.26719/ emhj.20.132

Received: 02/10/19; accepted: 06/04/20

Copyright (C) World Health Organization (WHO) 2021. Open Access. Some rights reserved. This work is available under the CC BY-NC-SA 3.o IGO license (https://creativecommons.org/licenses/by-nc-sa/3.o/igo).

\section{Introduction}

Depression is a common psychological disorder and like obesity, is a key contributor to morbidity and mortality (1). Not much research has been performed on the relationship between obesity and mental illness such as depression and anxiety. Depression can adversely affect quality of life and working ability (1). Treatment and management of obesity and depression or anxiety are costly; therefore, more studies are required to elucidate the association between obesity and psychological disorders to improve clinical management plans (2).

Previous studies have reported a connection between obesity and anxiety and depression, albeit with conflicting results $(3,4)$. Some studies have found a negative association of obesity with depression and anxiety (2), whereas others have shown a U-shaped association, meaning that underweight and overweight people are more likely to have depression and anxiety than those with normal weight $(5,6)$. Despite such evidence, some researchers have not found any relationship between body weight and depression and anxiety (7). Furthermore, some investigators have found an association only in men (8), while others have found a significant association only in women (5).

One of the major reasons for obesity in patients with psychological disorders is medication, which can lead to $2-17 \mathrm{~kg}$ weight gain over the course of clinical treatment. Adverse effects of these medications include reduced quality of life and cardiovascular disorders in patients with severe mental illness compared to the general population. In patients with severe weight gain after the first 3 months of beginning medication, lifestyle intervention is suggested (5).

It should be borne in mind that most studies in this area have been conducted in western countries and limited data are available from other regions. In particular, studying the relationship between obesity 
with depression and anxiety is important among MiddleEastern populations, where there is a specific pattern of obesity (9). Abdominal obesity is prevalent among adult women living in the Middle East. Moreover, previous studies have focused on general obesity, while it seems that the influence of fat distribution within the body on psychological disorders is more important than total body fat. Moreover, previous studies have focused on depression as the main psychological outcome, whereas other conditions like stress and psychological distress might also be associated with obesity. Given the limited details on the relationship between general and central adiposity and psychological disorders in the Middle East, the purpose of this study was to investigate whether obesity is associated with depression, anxiety and psychological distress among Iranian healthcare staff.

\section{Methods}

\section{Study participants}

We conducted a cross-sectional study within the framework of the Study on the Epidemiology of Psychiatric-Alimentary Health and Nutrition (SEPAHAN). Participants were adults aged 18-55 years selected from 50 healthcare centres of Isfahan Province, Islamic Republic of Iran. Details of the study protocol have been discussed previously (10). The study group comprised different categories of employees recruited from different health centres, with different lifestyle and socioeconomic status. So, there was no homogeneity in the study population. These differences were similar to those in wider society.

The required information in the SEPAHAN study was collected in 2 phases. First, a questionnaire that contained information on demographic and dietary data was sent to 10087 participants and 8691 returned the completed questionnaires (response rate $86.16 \%$ ). Second, information on psychological health was gathered and 6239 participants returned the completed questionnaires. After linking the completed questionnaires from the first and second phases, 4633 participants had given complete information on diet and psychological factors. We excluded under- and over-reporting of food intake (energy intake outside the range of $800-4200 \mathrm{kcal} /$ day). Finally, data on 4361 participants were analysed for general obesity and 3213 for central obesity. Participants gave signed informed consent to take part in the study.

\section{Anthropometric assessment}

Anthropometric data [body height and weight and waist circumference (WC)] were collected using a validated self-administered questionnaire (11). Body mass index (BMI) was categorized into normal $\left(\leq 24.9 \mathrm{~kg} / \mathrm{m}^{2}\right)$, overweight $\left(25.0-29.9 \mathrm{~kg} / \mathrm{m}^{2}\right)$ or obese $\left(\geq 30.0 \mathrm{~kg} / \mathrm{m}^{2}\right)$. The guidelines of the National Cholesterol Education Program were used to define abdominal obesity. Accordingly, participants were classified into 3 categories: normal WC ( $<80 \mathrm{~cm}$ for women, $<94 \mathrm{~cm}$ for men); level 1 abdominal obesity $(80-87.99 \mathrm{~cm}$ for women, $94-101.99 \mathrm{~cm}$ for men); and level 2 abdominal obesity ( $\geq 88 \mathrm{~cm}$ for women, $\geq 102 \mathrm{~cm}$ for men) (12).

The validity of self-reported anthropometric values was assessed in a pilot study including 200 individuals from the same population (11). These values were compared with actual measured values. There was a reasonable correlation between self-reported and measured values. The correlation coefficients were 0.95 $(P<0.001)$ for self-reported body weight, $0.83(P<0.001)$ for height, and $0.60(P<0.001)$ for WC versus corresponding measured values. The correlation coefficient for reportbased BMI (calculated from self-reported body height and weight) and the measurement-based BMI (calculated from measured body weight and height) was 0.70 $(P<0.001)$.

\section{Assessment of psychological profile}

Anxiety and depression were measured by the validated Iranian translation of the Hospital Anxiety and Depression Scale (HADS) (13). HADS is a screening tool used to measure symptoms of anxiety and depression. HADS consists of 2 subscales, with 7 items measuring anxiety and 7 items measuring depression. Items are rated on a 4-point scale (0-3), with higher scores indicating a higher level of anxiety and depression symptoms. The maximum score of HADS is 21 in each of the subscales. Scores of $\geq 11$ on either subscale were considered to be a severe form of depression or anxiety, 8-10 borderline and 0-7 normal (14).

Psychological distress was evaluated by the validated Iranian translation of the General Health Questionnaire (GHQ) with 12-items (15). GHQ-12 is a short, simple and easy-to-complete questionnaire that measures current and primary mental health, to determine if the respondent is at risk of developing psychological distress. Items are rated on a 4-point response scale comprising: 1 , less than usual; 2 , no more than usual; 3 , rather more than usual; and 4, much more than usual. The total score is 12 or 36 according to the scoring method used. We used the dichotomous scoring style (0-0-1-1). Total score ranges from 0 to 12. Higher scores indicate high levels of psychological distress (16). We considered poor mental health to be GHQ-12 score $\geq 4$.

\section{Statistical analysis}

Statistical analysis was performed using SPSS version 16 (SPSS Inc, Chicago, IL, USA). $P<0.05$ was considered significant. Data were analysed for the overall population as well as stratified by sex. General characteristics of study participants across different categories of BMI and WC were examined by analysis of variance or $\chi^{2}$ test. Prevalence of mental illness across categories of BMI and WC was assessed by $\chi^{2}$ test. Binary logistic regression was performed to explore the relationship between general and central obesity and psychological disorders. This analysis was adjusted for possible confounders including age (continuous), sex (male/female), marital status (single/married/divorced), education ( below high school, university graduate), smoking (non-smokers,/ex-smok- 
ers/current smokers) and physical activity (never, $<1 \mathrm{~h} /$ week, 1-3 h/week and > $3 \mathrm{~h} /$ week). In all multivariate models, those with normal BMI or WC were considered as a reference. The logistic regression was applied for different levels of mental illnesses: borderline and severe forms of depression, anxiety and high psychological distress were considered as separate outcomes in the analysis. We also used the combined variable of these 2 levels in the analysis. The growing trend of odds ratios across BMI and WC categories was examined through the use of median values of BMI and WC in each category as a continuous variable.

\section{Results}

The general characteristics of the study participants across BMI and waist circumference categories are indicated in Table 1.

Prevalence of overweight and obesity was 37\% (43.7\% for men and 10\% for women) and 9.7\% (9.3\% for males and $10.0 \%$ for females) in the overall population, respectively. Prevalence of abdominal obesity (level 2) was 33.1\% for the overall population (18.3\% for men and $39.7 \%$ for women). Prevalence of abdominal obesity (level 2) was 30.4\% for the overall population ( $16.8 \%$ for men and $38.4 \%$ for women).

Prevalence of mental illnesses across different categories of BMI in the whole population as well as by gender is shown in Figure 1. Prevalence of severe depression and anxiety was significantly higher in obese participants than in other categories. When the analyses were stratified by sex, such significant differences were only seen among women. Prevalence of depression, anxiety and high psychological distress among abdominally obese (level 2) participants was more than that in other categories of WC in the whole population.
The same findings were also observed among women in our stratified analysis.

Sex-stratified analysis revealed no significant relationship between general obesity and depression, anxiety and high psychological distress among men (Table 2). However, abdominal obesity (WC > $102 \mathrm{~cm}$ ) was inversely associated with severe depression in men. In women, a significant relationship was seen between obesity and severe depression [odds ratio $(\mathrm{OR})=1.45$, $95 \%$ confidence interval $(\mathrm{CI})=1.0-2.11]$ as well as severe anxiety $(\mathrm{OR}=1.66,95 \% \mathrm{CI}=1.03-2.67)$ (Table 3). However, after adjustment for confounders, these relationships disappeared. Significant relationships were observed between abdominal obesity and depression, in particular severe depression among women; such that abdominally obese women had 63\% (OR $=1.63,95 \% \mathrm{CI}=1.19-2.24)$ and $28 \%(\mathrm{OR}=1.28,95 \% \mathrm{CI}=1.03-1.59)$ higher risk for severe depression and depression (combined borderline and severe depression), respectively, than those with normal WC. Both relationships disappeared after adjusting for confounding variables. Abdominal obesity was significantly associated with anxiety and severe anxiety among women, either before or after taking confounders into account. Although abdominally obese women were $31 \%$ more likely to have psychological distress, adjustment for confounders made the association disappears.

\section{Discussion}

We found an inverse association between abdominal obesity (WC > $102 \mathrm{~cm}$ ) and severe depression among men. In women, abdominal obesity was significantly associated with anxiety, before and after taking confounders into account. No significant association was seen between abdominal obesity and psychological distress in either sex after controlling for potential confounders.

\begin{tabular}{|c|c|c|c|c|c|c|c|c|}
\hline \multirow[t]{2}{*}{ Whole population } & \multicolumn{3}{|c|}{ BMI categories $^{b}$} & \multicolumn{5}{|c|}{ WC categories ${ }^{c}$} \\
\hline & Normal & Overweight & Obese & $\mathbf{P}$ & Normal & $\begin{array}{c}\text { Abdominal } \\
\text { obesity } \\
\text { level } 1\end{array}$ & $\begin{array}{c}\text { Abdominal } \\
\text { obesity } \\
\text { level } 2\end{array}$ & $P^{*}$ \\
\hline Age (yr) & $34.2(7.8)$ & $38.3(7.3)$ & $39.8(7.3)$ & $<0.001$ & $34.8(7.8)$ & $36.8(7.4)$ & $38.7(7.2)$ & $<0.001$ \\
\hline Weight (kg) & $61(8.8)$ & $75.3(9.2)$ & $87.1(16.9)$ & $<0.001$ & $62.6(11.6)$ & $69.5(12.8)$ & $74.8(11.7)$ & $<0.001$ \\
\hline BMI $\left(\mathrm{kg} / \mathrm{m}^{2}\right)$ & $22.1(2.1)$ & $27(1.3)$ & $33.9(7.3)$ & $<0.001$ & $22.6(3.8)$ & $25.3(3.1)$ & $28.2(4.2)$ & $<0.001$ \\
\hline $\mathrm{WC}(\mathrm{cm})$ & $76.8(17.1)$ & $87.7(17.4)$ & $96.6(20.4)$ & $<0.001$ & $78.3(8.1)$ & $88.6(7.3)$ & $98.48(8.3)$ & $<0.001$ \\
\hline Married (\%) & 72.7 & 90.8 & 89.7 & $<0.001$ & 74.1 & 86.2 & 90.0 & $<0.001$ \\
\hline University graduates (\%) & 62.2 & 54.2 & 46.7 & $<0.001$ & 63.8 & 63.0 & 53.8 & $<0.001$ \\
\hline Current smokers (\%) & 13.7 & 15.2 & 14.9 & 0.082 & 12.8 & 12.5 & 15.8 & 0.065 \\
\hline Supplement use (\%) & 8.3 & 6.7 & 6.5 & 0.104 & 8.6 & 9.2 & 7.8 & 0.524 \\
\hline OCP use (\%) & $3 \cdot 3$ & 2.2 & 3.4 & 0.103 & 2.1 & 3.2 & 4.2 & 0.013 \\
\hline Self-reported diabetes (\%) & 0.9 & 2.3 & 3.1 & $<0.001$ & 0.8 & 1.7 & 2.5 & 0.005 \\
\hline
\end{tabular}

aAll values are mean (standard deviation), unless indicated.

${ }^{b}$ Normal weight $\left(\leq 24.9 \mathrm{~kg} / \mathrm{m}^{2}\right)$, overweight $\left(25.0-29.9 \mathrm{~kg} / \mathrm{m}^{2}\right)$ and obesity $\left(\geq 30.0 \mathrm{~kg} / \mathrm{m}^{2}\right)$

'Normal ( $<80 \mathrm{~cm}$ for women, $<94 \mathrm{~cm}$ for men), abdominal obesity level $1(80-87.99 \mathrm{~cm}$ for women, $94-101.99 \mathrm{~cm}$ for men), abdominal obesity level 2 ( $\geq 88 \mathrm{~cm}$ for women, $\geq 102 \mathrm{~cm}$ for men). *Obtained from analysis of variance or ?2.

$\mathrm{BMI}=$ body mass index $\mathrm{OCP}=$ oral contraceptive pill; $\mathrm{WC}=$ waist circumference . 
Figure 1 Prevalence of depression, anxiety and psychological distress according to body mass index (BMI) and waist circumference (WC) categories in the whole population and stratified by sex. (A) Based on BMI categories in the whole population; (B) based on BMI categories in men; (C) based on BMI categories in women; (D) based on WC categories in the whole population; (E) based on WC categories in men; and (F) based on WC categories in women.

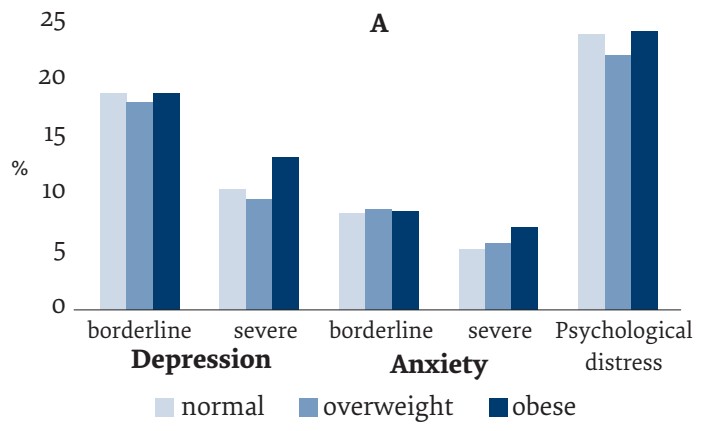

35
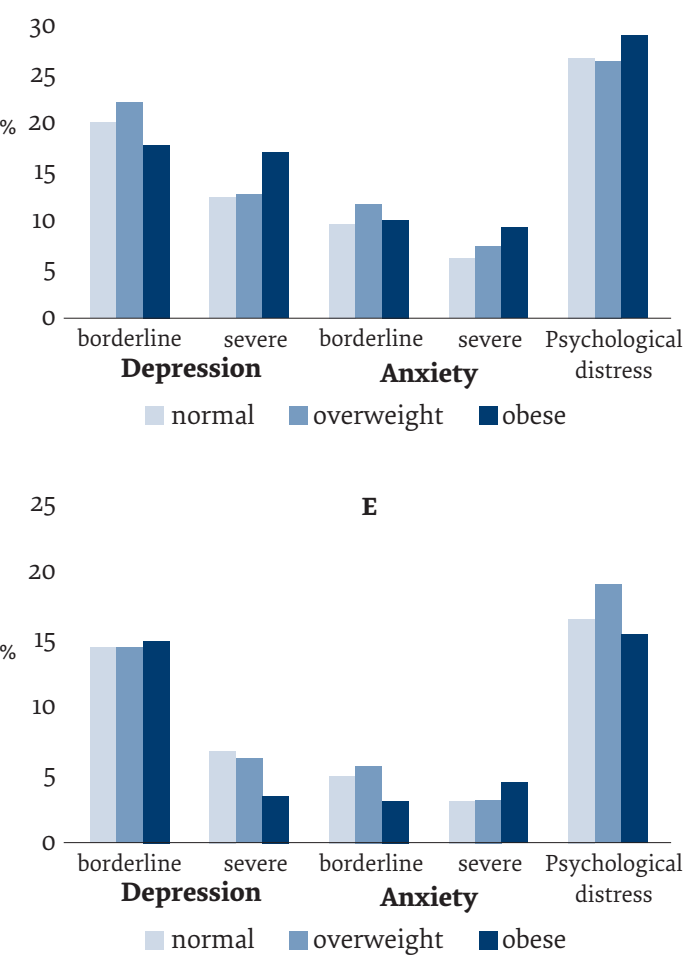

Prevalence of depression, anxiety and high psychological distress in developing countries has grown in parallel with increasing prevalence of overweight and obesity. In the current study, we did not observe any significant association between BMI and these mental illnesses. A recent systematic review showed a significant, but weak, cross-sectional relationship between obesity and depression (17). While some crosssectional studies have shown a positive association between depressive symptoms and obesity $(5,7,18)$, others have shown an inverse relationship $(19,20)$. A negative relationship between central obesity and depressive symptoms has also been reported among Korean women (21). Revenes et al. (22) suggested that BMI was not related to depression and even might have some preventive effects against anxiety. Rebert et al. $(7,18)$ showed that obesity is positively related to depression, might
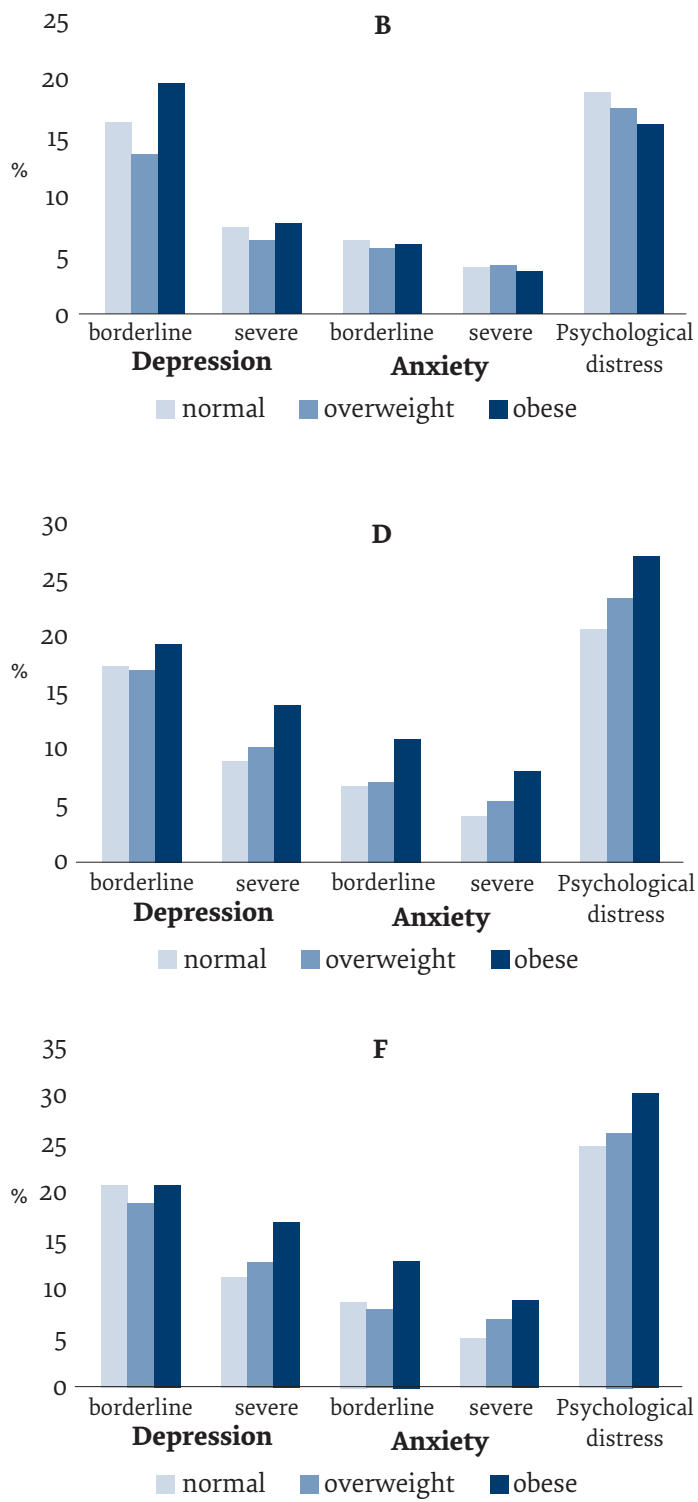

worsen mental disorders, and aggravates pessimism and satisfaction. A recent meta-analysis showed a positive association between BMI and depression in 17 community-based cross-sectional studies in adults (23). It is worth noting that all previous studies have been conducted in developed nations, which shows that ethnic differences can affect the strength of the relationship between obesity and depression. Additionally, the current study was from the Middle East, where a particular pattern of obesity is prevalent (9). Furthermore, it seems that severity of obesity influences the association between obesity and depression, anxiety and high psychological distress. Some researchers have suggested that this association might be limited to individuals with extreme obesity. For instance, Onyike et al. (24) found that, after controlling potential confounders, the association remained significant only in severely obese 
Table 2 Multivariable-adjusted ORs and 95\% CIs for depression, anxiety and high psychological distress across categories of BMI and waist circumference for men ${ }^{\mathrm{a}}$

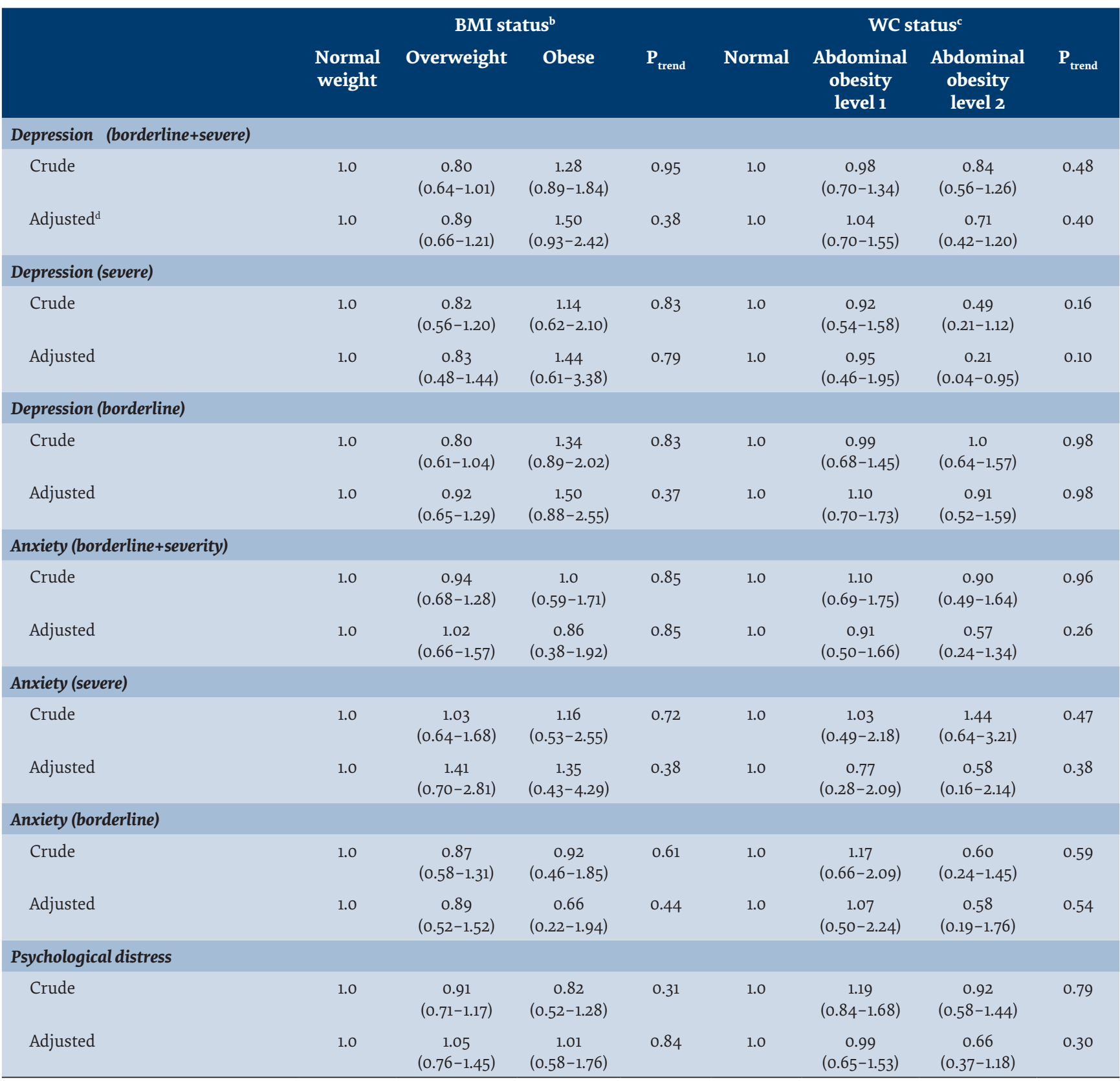

${ }^{a}$ Severe anxiety and depression was defined as Hospital Anxiety and Depression Scale score $\geq 11 ; 8-10$ was considered as borderline. Psychological distress was defined as General Health Questionnaire score $\geq 4$

${ }^{b}$ Normal weight $\left(\leq 24.9 \mathrm{~kg} / \mathrm{m}^{2}\right)$, overweight $\left(25.0-29.9 \mathrm{~kg} / \mathrm{m}^{2}\right)$ and obesity $\left(\geq 30.0 \mathrm{~kg} / \mathrm{m}^{2}\right)$.

'Normal $(<94 \mathrm{~cm})$, abdominal obesity level $1(94-101.99 \mathrm{~cm})$, abdominal obesity level $2(\geq 102 \mathrm{~cm})$.

${ }^{d}$ Adjusted for age, marital status, education, smoking and physical activity.

$\mathrm{BMI}=$ body mass index; $\mathrm{CI}=$ confidence interval; $\mathrm{OR}=$ odds ratio; $W C=$ waist circumference.

$\left(\mathrm{BMI} \geq 40 \mathrm{~kg} / \mathrm{m}^{2}\right)$ individuals. Although overweight and obesity were highly prevalent in our study, the prevalence of severe obesity was not so high. Different types of obesity and location of fat accumulation might affect psychological disorders. We discovered a significant positive relationship between abdominal obesity and depression, anxiety and high psychological distress in crude models. However, the relationships disappeared after adjusting for potential confounders. A positive association was reported between waist to height ratio and anxiety in women, independent of confounders. However, some studies have proposed that central obesity does not impose further risk for depressive disorders compared with that for general obesity $(25,26)$.

In the current study, there was no association between general obesity and depression, anxiety and high psychological distress, neither in men nor in women. However, while there was a positive link between abdominal obesity and these psychological disorders in women, an inverse relationship between abdominal obesity and severe depression was observed in men. Earlier studies have mostly shown that abdominal obesity is connected with these psychological disorders 
Table 3 Multivariable-adjusted odds ratios and 95\% CIs for depression, anxiety and high psychological distress across categories of BMI and waist circumference for women ${ }^{a}$

\begin{tabular}{|c|c|c|c|c|c|c|c|c|}
\hline & \multirow[b]{2}{*}{$\begin{array}{c}\text { Normal } \\
\text { weight }\end{array}$} & \multicolumn{2}{|c|}{ BMI status $^{\mathbf{b}}$} & \multirow[b]{2}{*}{$\boldsymbol{P}_{\text {trend }}$} & \multicolumn{3}{|c|}{ WC status ${ }^{c}$} & \multirow[b]{2}{*}{$\boldsymbol{P}_{\text {trend }}$} \\
\hline & & Overweight & Obese & & Normal & $\begin{array}{l}\text { Action } \\
\text { level } 1\end{array}$ & $\begin{array}{l}\text { Action } \\
\text { level } 2\end{array}$ & \\
\hline \multicolumn{9}{|c|}{ Depression (borderline+severe) } \\
\hline Crude & 1.0 & $\begin{array}{c}1.14 \\
\left(0.95^{-1.37)}\right.\end{array}$ & $\begin{array}{c}1.15 \\
(0.87-1.53)\end{array}$ & 0.14 & 1.0 & $\begin{array}{c}0.99 \\
(0.78-1.26)\end{array}$ & $\begin{array}{c}1.28 \\
(1.03-1.59)\end{array}$ & 0.02 \\
\hline Adjusted $^{\mathrm{d}}$ & 1.0 & $\begin{array}{c}1.03 \\
(0.82-1.30)\end{array}$ & $\begin{array}{c}0.86 \\
(0.60-1.24)\end{array}$ & 0.61 & 1.0 & $\begin{array}{c}0.98 \\
(0.73-1.31)\end{array}$ & $\begin{array}{c}1.02 \\
(0.76-1.38)\end{array}$ & 0.83 \\
\hline \multicolumn{9}{|c|}{ Depression (severe) } \\
\hline Crude & 1.0 & $\begin{array}{c}1.11\left(0.85^{-}\right. \\
1.45)\end{array}$ & $\begin{array}{c}1.45 \\
(1.0-2.11)\end{array}$ & 0.05 & 1.0 & $\begin{array}{c}1.13 \\
(0.80-1.61)\end{array}$ & $\begin{array}{c}1.63 \\
(1.19-2.24)\end{array}$ & 0.001 \\
\hline Adjusted & 1.0 & $\begin{array}{c}0.90 \\
(0.64-1.25)\end{array}$ & $\begin{array}{c}0.84 \\
(0.51-1.37)\end{array}$ & 0.42 & 1.0 & $\begin{array}{c}1.20 \\
(0.79-1.82)\end{array}$ & $\begin{array}{c}1.17 \\
(0.77-1.79)\end{array}$ & 0.50 \\
\hline \multicolumn{9}{|c|}{ Depression (borderline) } \\
\hline Crude & 1.0 & $\begin{array}{c}1.15 \\
(0.93-1.43)\end{array}$ & $\begin{array}{c}0.97 \\
(0.68-1.38)\end{array}$ & 0.59 & 1.0 & $\begin{array}{c}0.90 \\
(0.68-1.20)\end{array}$ & $\begin{array}{c}1.08 \\
(0.83-1.41)\end{array}$ & 0.48 \\
\hline Adjusted & 1.0 & $\begin{array}{c}1.14 \\
(0.87-1.50)\end{array}$ & $\begin{array}{c}0.89 \\
(0.57-1.38)\end{array}$ & 0.99 & 1.0 & $\begin{array}{c}0.85 \\
(0.59-1.21)\end{array}$ & $\begin{array}{c}0.94 \\
(0.66-1.33)\end{array}$ & 0.79 \\
\hline \multicolumn{9}{|c|}{ Anxiety (borderline+severity) } \\
\hline Crude & 1.0 & $\begin{array}{c}1.27 \\
(1.01-1.59)\end{array}$ & $\begin{array}{c}1.33 \\
(0.94-1.87)\end{array}$ & 0.02 & 1.0 & $\begin{array}{c}1.12 \\
(0.81-1.54)\end{array}$ & $\begin{array}{c}1.80 \\
(1.36-2.38)\end{array}$ & $<0.001$ \\
\hline Adjusted & 1.0 & $\begin{array}{c}1.0 \\
\left(0.75^{-1.33}\right)\end{array}$ & $\begin{array}{c}0.96 \\
(0.62-1.49)\end{array}$ & 0.90 & 1.0 & $\begin{array}{c}1.09 \\
(0.74-1.61)\end{array}$ & $\begin{array}{c}1.47 \\
(1.01-2.14)\end{array}$ & 0.03 \\
\hline \multicolumn{9}{|c|}{ Anxiety (severe) } \\
\hline Crude & 1.0 & $\begin{array}{c}1.27 \\
(0.91-1.80)\end{array}$ & $\begin{array}{c}1.66 \\
(1.03-2.67)\end{array}$ & 0.02 & 1.0 & $\begin{array}{c}1.42 \\
(0.88-2.28)\end{array}$ & $\begin{array}{c}1.99 \\
(1.30-3.07)\end{array}$ & 0.001 \\
\hline Adjusted & 1.0 & $\begin{array}{c}1.03 \\
(0.67-1.59)\end{array}$ & $\begin{array}{c}1.12 \\
(0.60-2.11)\end{array}$ & 0.72 & 1.0 & $\begin{array}{c}1.56 \\
(0.87-2.80)\end{array}$ & $\begin{array}{c}1.86 \\
(1.04-3.34)\end{array}$ & 0.04 \\
\hline \multicolumn{9}{|c|}{ Anxiety (borderline) } \\
\hline Crude & 1.0 & $\begin{array}{c}1.29 \\
(0.97-1.70)\end{array}$ & $\begin{array}{c}1.14 \\
(0.73-1.77)\end{array}$ & 0.19 & 1.0 & $\begin{array}{c}0.94 \\
(0.63-1.41)\end{array}$ & $\begin{array}{c}1.66 \\
(1.18-2.35)\end{array}$ & 0.002 \\
\hline Adjusted & 1.0 & $\begin{array}{c}0.99 \\
(0.69-1.41)\end{array}$ & $\begin{array}{c}0.89 \\
(0.51-1.54)\end{array}$ & 0.73 & 1.0 & $\begin{array}{c}0.84 \\
(0.52-1.37)\end{array}$ & $\begin{array}{c}1.27 \\
(0.80-2.0)\end{array}$ & 0.21 \\
\hline \multicolumn{9}{|c|}{ Psychological distress } \\
\hline Crude & 1.0 & $\begin{array}{c}0.98 \\
(0.81-1.20)\end{array}$ & $\begin{array}{c}1.13 \\
(0.83-1.52)\end{array}$ & 0.56 & 1.0 & $\begin{array}{c}1.06 \\
(0.82-1.38)\end{array}$ & $\begin{array}{c}1.31 \\
(1.03-1.66)\end{array}$ & 0.02 \\
\hline Adjusted & 1.0 & $\begin{array}{c}0.94 \\
(0.74-1.21)\end{array}$ & $\begin{array}{c}0.84 \\
(0.57-1.24)\end{array}$ & 0.39 & 1.0 & $\begin{array}{c}1.15 \\
(0.85-1.57)\end{array}$ & $\begin{array}{c}1.17 \\
(0.86-1.60)\end{array}$ & 0.33 \\
\hline
\end{tabular}

aSevere anxiety and depression defined as Hospital Anxiety and Depression Scale score $\geq 11 ; 8-10$ was considered as borderline'. Psychological distress was defined as General Health Questionnaire score $\geq 4$.

${ }^{b}$ Normal weight $\left(\leq 24.9 \mathrm{~kg} / \mathrm{m}^{2}\right)$, overweight $\left(25.0-29.9 \mathrm{~kg} / \mathrm{m}^{2}\right)$ and obesity $\left(\geq 30.0 \mathrm{~kg} / \mathrm{m}^{2}\right)$.

'Normal $(<80 \mathrm{~cm})$, abdominal obesity level $1(80-87.99 \mathrm{~cm})$, abdominal obesity level $2(\geq 88 \mathrm{~cm})$.

${ }^{d}$ Adjusted for age, marital status, education, smoking and physical activity.

$B M I=$ body mass index; $C I=$ confidence interval; $\mathrm{OR}=$ odds ratio; $\mathrm{WC}=$ waist circumference

in either sex (22). Our results are in agreement with some findings (27) but in contrast with others (28). The negative association between severe depression and obesity in men has also been shown in some studies (29). These conflicting results might be explained by the different pattern of abdominal obesity among men and women in different countries and greater relationship between abdominal obesity and depression in women (30). The possible mechanisms through which abdominal obesity might affect depression, anxiety and high psychological distress are unknown. Poor self-esteem, unhealthy dietary habits (31), binge eating as well as decreased physical activity (32) in abdominally obese individuals might provide some reasons. Additionally, abdominalobesity-related chronic conditions such as diabetes and cardiovascular disease might affect depression, anxiety and high psychological distress. These conditions can cause vascular damage and earlier studies have suggested that vascular damage in brain might predict depression (33). Abdominal obesity is related to higher inflammation. Increased concentrations of inflammatory biomarkers might also contribute to depression (34). Cortisol secretion (35) and sex-dependent steroid hormones (36) and their dysregulation occur in individuals with 
abdominal obesity with depression, anxiety and high psychological distress. Both depression and anxiety are involved in the hypothalamic-pituitary-adrenocortical axis hyperactivity that could result in increased cortisol secretion.

Increased appetite and reduced physical activity are common symptoms of depression. Initiation or maintenance of exercise programmes or diet change can be affected by reduced motivation or self-efficacy associated with depression or anxiety. Depression or anxiety can enhance risk of weight gain by its impact on binge eating, particularly among women. Medications used to manage mood or anxiety disorders may also lead to weight gain. Some studies have suggested that obesity causes or contributes to depression or anxiety. The stigma attached to obesity (especially for women) may contribute to depression, and this stigma may vary by race/ethnicity or socioeconomic status. Physical activities decrease because of obesity or obesity-related chronic illnesses. Obesity may increase risk of depression and anxiety through distressing physical symptoms or involvement in rewarding or pleasurable activities. Finally, depression and obesity may be linked by environmental or biological factors (4).

Our study had several strengths. This was one of the most comprehensive studies with a large sample size in developing countries. The most prevalent psychological disorders including depression, anxiety and psychological distress were examined using validated questionnaires. Sex-stratified subanalysis allowed us to identify sex differences in the investigated associations. Moreover, the analyses were adjusted for several well-known confounding factors. There were also some limitations that could have affected our results. The cross-sectional nature of the study meant that causality could not be established. However, our validation study demonstrated that self-reported values of anthropometric indices could provide reasonably valid data. Questionnaire-based data were used for assessment of depression, anxiety and high psychological distress. Although these questionnaires were valid instruments to measure symptoms $(13,15)$, they cannot be used as diagnostic tools for these psychological disorders. Confounding variables such eating disorders, use of psychiatric medications affecting weight, and pregnancy were not controlled in our study. Finally, the absence of data on socioeconomic status and its relation to obesity and mental status was another limitation.

In conclusion, this study revealed that abdominal obesity was associated with anxiety only among Iranian adult women. We were unable to find any evidence confirming the relationship between general obesity and depression, anxiety and high psychological distress in this population. Future research, particularly of a prospective nature, is warranted to confirm these findings.

Funding: None.

Competing interests: None declared.

\section{Relation entre obésité et dépression, anxiété et détresse psychologique parmi le personnel de santé iranien \\ Résumé}

Contexte: Les troubles psychologiques associées à l'obésité constituent un facteur essentiel qui contribue à la morbidité et à la mortalité.

Objectifs : Évaluer le lien entre l'obésité générale et abdominale et la dépression et l'anxiété parmi le personnel de santé iranien.

Méthodes: La présente étude transversale a été menée dans le cadre de l'étude sur l'épidémiologie de la santé psychologique, alimentaire et nutritionnelle. Au total, 4361 membres du personnel de santé iranien ont été dépistés pour l'obésité générale et 3213 pour l'obésité abdominale. Le surpoids et l'obésité ont été définis respectivement en fonction d'un indice de masse corporelle de 25,0-29,9 et supérieur ou égal à 30,0 kg/m². L'obésité abdominale a été définie par un tour de taille supérieur ou égal à $88 \mathrm{~cm}$ pour les femmes et à $102 \mathrm{~cm}$ pour les hommes. Les versions iraniennes validées de l'échelle hospitalière d'anxiété et de dépression et du questionnaire général de santé ont été utilisées pour évaluer la dépression et l'anxiété.

Résultats : L'analyse stratifiée par sexe n'a révélé aucune relation significative entre l'obésité générale, la dépression et l'anxiété chez les hommes. Cependant, nous avons trouvé une association inverse entre obésité abdominale (tour de taille $>102 \mathrm{~cm}$ ) et dépression sévère chez les hommes. Chez les femmes, l'obésité abdominale était associée de manière significative à l'anxiété, avant et après la prise en compte des facteurs de confusion. Aucune association significative n'a été observée entre l'obésité abdominale et la détresse psychologique dans les deux sexes après contrôle des facteurs de confusion potentiels.

Conclusions: L'obésité abdominale était associée à l'anxiété chez les femmes adultes iraniennes, mais pas chez les hommes. Par ailleurs, des études prospectives sont nécessaires pour confirmer ces résultats. 


\section{العلاقة بين السمنة والاكتئاب و القلق والضائقة النفسية بين العاملين الإيرانيين في بجال الرعاية الصحية مطهر حيدري-بني، فاطمة سليمان، حامد أفشار، حسين خسروي -بورجيني، عهار كشتيلي، أحمد إسماعيل زاده، بيمان أديبي}

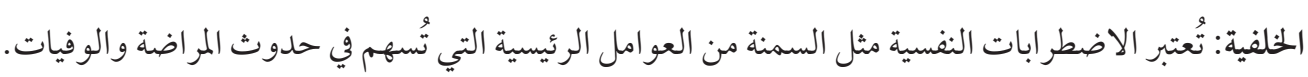
الأهداف: هدفت هذه الدراسة إلى تقييم العلاقة بين السمنة العامة وسمنة البطن وبين الاكتئاب والقلق لدى العاملين الإيرانيين في مجال الرعاية

طرق البحث: أجريت هذه الدر اسة المقطعية كجزء من دراسة حول وبائيات الصحة التغذوية النغسيةٍ والتغذية. وبلغ بجموع العاملين الإيرانيين في

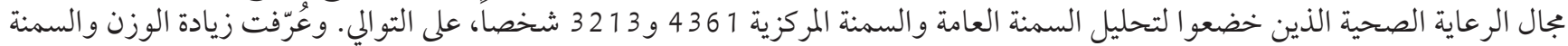

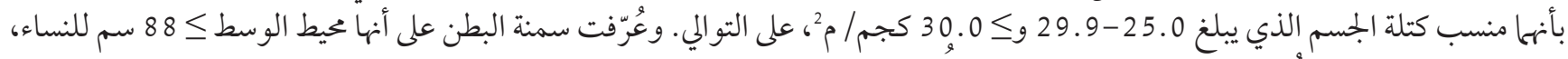

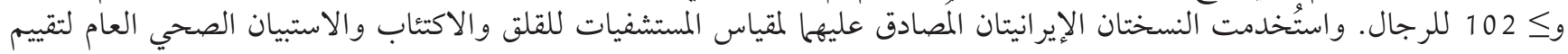
الاكتئاب و القلق.

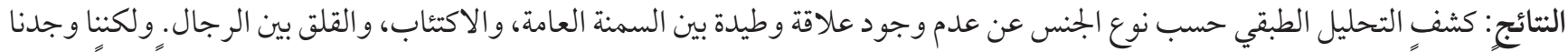

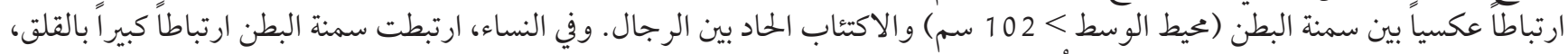

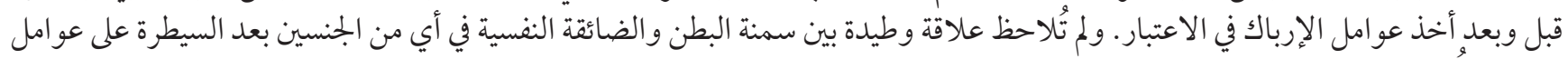
الإرباك المحتملة.

الاستنتاجات: ارتبطت سمنة البطن بمشاعر القلق في النساء البالغات الإيرانيات ولكن ليس الرجال. كما يلزم إجر اء دراسات استباقية خاصة لتأكيد هذه النتائج.

\section{References}

1. Chapman D, Perry G, Strine T. The vital link between chronic disease and depressive disorders. Prev Chronic Dis. 2005 Jan;2(1):A14. PMID:15670467

2. Faith M, Butryn M, Wadden T, Fabricatore A, Nguyen A, Heymsfield S. Evidence for prospective associations among depression and obesity in population-based studies. Obes Rev. 2011 May;12(5):e438-53. http://dx.doi.org/10.1111/j.1467-789X.2010.00843.X PMID: 21414128

3. Rohde P, Ichikawa L, Simon G, Ludman E, Linde J, Jeffery R, et al. Associations of child sexual and physical abuse with obesity and depression in middle-aged women. Child Abuse Negl. 2008 Sep;32(9):878-87. http://dx.doi.org/10.1016/j.chiabu.2007.11.004 PMID:18945487

4. Simon G, Ludman E, Linde J, Operskalski B, Ichikawa L, Rohde P, et al. Association between obesity and depression in middle-aged women. Gen Hosp Psychiatry. 2008 Jan-Feb;30(1):32-9. http://dx.doi.org/10.1016/j.genhosppsych.2007.09.001 PMID:18164938

5. Carpenter K, Hasin D, Allison D, Faith M. Relationships between obesity and DSM-IV major depressive disorder, suicide ideation, suicide attempts: results from a general population study. Am J Public Health. 2000 Feb;90(2):251-7. http://dx.doi. org/10.2105/ajph.90.2.251 PMID:10667187

6. Johnston E, Johnson S, Mcleod P, Jonhston M. The relation of body mass index to depressive symptoms. Can J Public Health. 2004 May-Jun;95(3):179-83. http://dx.doi.org/10.1007/BF03403643 PMID:15191118

7. $\quad$ Roberts R, Kaplan G, Shema S, Strawbridge W. Are the obese at greater risk for depression? Am J Epidemiol. 2000 Jul 15;152(2):163-70. http://dx.doi.org/10.1093/aje/152.2.163 PMID:10909953

8. Milaneschi Y, Simonsick E, Vogelzangs N, Strotmeyer E, Yaffe K, Harris T, et al. Leptin, abdominal obesity and onset of depression in older men and women. J Clin Psychiatry. 2012 Sep;73(9):1205-11. http://dx.doi.org/10.4088/JCP.11m07552 PMID:22687702

9. Azizi F, Azadbakht L, Mirmiran P. Trends in overweight, obesity and central fat accumulation among Tehranian adults between 1998-1999 and 2001-2002: Tehran lipid and glucose study. Ann Nutr Metab. 2005 Jan-Feb;49(1):3-8. http://dx.doi. org/10.1159/000084171 PMID:15735362

10. Adibi P, Hassanzadeh-Keshteli A, Esmaillzadeh A, Afshar H, Roohafza H, Bagherian-Sararoudi R, et al. The study on the epidemiology of psychological, alimentary health and nutrition (SEPAHAN): overview of methodology. J Res Med Sci. 2012;17(5):S292-S8.

11. Aminian-far S, Saneei P, Nouri M, Shafiei R, Keshteli AH, Esmaillzadeh A, Adibi P. Validation study of self-reported anthropometric indexes among Isfahan medical sciences university staff. J Isfahan Med Sch. 2015; 33(346):1318-27 (in Farsi).

12. Executive Summary of the Third Report of the National Cholesterol Education Program (NCEP) Expert Panel on Detection, Evaluation, and Treatment of High Blood Cholesterol in Adults (Adult Treatment Panel III). JAMA. 2001 May 16;285(19):2486-97. http://dx.doi.org/10.1001/jama.285.19.2486 PMID:11368702 
13. Montazeri A, Vahdaninia M, Ebrahimi M, Jarvandi S. The Hospital Anxiety and Depression Scale (HADS): translation and validation study of the Iranian version. Health Qual Life Outcomes. 2003 Apr 28;1:14-9. http://dx.doi.org/10.1186/1477-7525-1-14 PMID:12816545

14. Brennan C, Worrall-Davies A, McMillan D, Gilbody S, House A. The Hospital Anxiety and Depression Scale: a diagnostic meta-analysis of case-finding ability. J Psychosom Res. 2010 Oct;69(4):371-8. http://dx.doi.org/10.1016/j.jpsychores.2010.04.006 PMID:20846538

15. Montazeri A, Harirchi A, Shariati M, Garmaroudi G, Ebadi M, Fateh A. The 12-item General Health Questionnaire (GHQ12): translation and validation study of the Iranian version. Health Qual Life Outcomes. 2003 Nov13;1:66-70. http://dx.doi. org/10.1186/1477-7525-1-66 PMID:14614778

16. Salama-Younes M, Montazeri A, Ismail A, Roncin C. Factor structure and internal consistency of the 12-item General Health Questionnaire (GHQ-12) and the Subjective Vitality Scale (VS), and the relationship between them: a study from France. Health Qual Life Outcomes. 2009 Mar 5;7:22-8. http://dx.doi.org/10.1186/1477-7525-7-22 PMID:19265516

17. Atlantis E, Baker M. Obesity effects on depression: systematic review of epidemiological studies. int J Obes. 2008 Jun;32(6):88191. http://dx.doi.org/10.1038/ijo.2008.54 PMID:18414420

18. Roberts R, Strawbridge W, Deleger S, Kaplan G. Are the fat more jolly? Ann Behav Med. 2002 Summer;24(3):169-80. http://dx.doi. org/10.1207/S15324796ABM2403_02 PMID:12173674

19. Goodman E, Whitaker R. A prospective study of the role of depression in the development and persistence of adolescent obesity. Pediatrics. 2002 Sep;110(3):497-504. http://dx.doi.org/10.1542/peds.110.3.497 PMID:12205250

20. Richardson L, Davis R, Poulton R, McCauley E, Moffitt T, Caspi A, et al. A longitudinal evaluation of adolescent depression and adult obesity. Arch Pediatr Adolesc Med. 2003 Aug;157(8):739-45. http://dx.doi.org/10.1001/archpedi.157.8.739 PMID:12912778

21. Yim G, Ahn Y, Cho J, Chang Y, Ryo S, Lim JY, et al. The "jolly fat" effect in middle-aged Korean women. J Womens Health (Larchmt). 2017 Nov;26(11):1236-43. http://dx.doi.org/10.1089/jwh.2016.6254 PMID:28922089

22. Rivenes A, Harvey S, Mykletun A. The relationship between abdominal fat, obesity, and common mental disorders: results from the HUNT Study. J Psychosom Res. 2009 Apr;66(4):269-75. http://dx.doi.org/10.1016/j.jpsychores.2008.07.012 PMID:19302883

23. de Wit L, Luppino F, van Straten A, Penninx B, Zitman F, Cuijpers P. Depression and obesity: a meta-analysis of community-based studies. Psychiatry Res. 2010 Jul 30;178(2):230-5. http://dx.doi.org/10.1016/j.psychres.2009.04.015 PMID:20462641

24. Onyike C, Crum R, Lee H, Lyketsos C, Eaton W. Is obesity associated with major depression? Results from the Third National Health and Nutrition Examination Survey. Am J Epidemiol. 2003 Dec 15;158(12):1139-47. http://dx.doi.org/10.1093/aje/kwg275 PMID:14652298

25. Hach I, Ruhl U, Klotsche J, Klose M, Jacobi F. Associations between waist circumference and depressive disorders. J Affect Disord. 2006 Jun;92(2-3):305-8. http://dx.doi.org/10.1016/j.jad.2006.01.023 PMID:16503357

26. Ho R, Niti M, Kua E, Ng T. Body mass index, waist circumference, waist-hip ratio and depressive symptoms in Chinese elderly: a population-based study. Int J Geriatr Psychiatry. 2008 Apr;23(4):401-8. http://dx.doi.org/10.1002/gps.1893 PMID:17879255

27. Zhao G, Ford E, Li C, Tsai J, Dhingra S, Balluz L. Waist circumference, abdominal obesity, and depression among overweight and obese U.S. adults: National Health and Nutrition Examination Survey 2005-2006. BMC Psychiatry. 2011 Aug 11;11:130-9. http:// dx.doi.org/10.1186/1471-244X-11-130 PMID:21834955

28. Vogelzangs N, Kritchevsky S, Beekman A, Brenes G, Newman A, Satterfield S, et al. Obesity and onset of significant depressive symptoms: results from a prospective community-based cohort study of older men and women. J Clin Psychiatry. 2010 Apr;71(4):391-9. http://dx.doi.org/10.4088/JCP.08m04743blu PMID:20021992

29. Zhou Q, Wang T, Basu K. Negative association between BMI and depressive symptoms in middle aged and elderly Chinese: results from a national household survey. Psychiatry Res. 2018 Nov; 269:571-8. https://doi.org/10.1016/j.psychres.2018.08.107

30. Latner JD, Durso LE, Mond JM. Health and health-related quality of life among treatment-seeking overweight and obese adults: associations with internalized weight bias. J Eat Disord. 2013 Jan 22;1:3. http://dx.doi.org/10.1186/2050-2974-1-3 PMID:24764526

31. Laitinen J, Pietilainen K, Wadsworth M, Sovio U, Jarvelin M. Predictors of abdominal obesity among 31-year-old men and women born in Northern Finland in 1966. Eur J Clin Nutr. 2004 Jan;58(1):180-90. http://dx.doi.org/10.1038/sj.ejcn.1601765 PMID:14679384

32. Cassidy K, Kotynia-English R, Acres J, Flicker L, Lautenshlager N, Almeida O. Association between lifestyle factors and mental health measures among community-dwelling older women. Aust N Z J Psychiatry. 2004 Nov-Dec;38(11-12):940-7. http://dx.doi. org/10.1080/j.1440-1614.2004.01485.x PMID:15555029

33. Brown L, Majumdar S, Newman S, Johnson J. History of depression increases risk of type 2 diabetes in younger adults. Diabetes Care. 2005 May;28(5):1063-7. http://dx.doi.org/10.2337/diacare.28.5.1063 PMID:15855568

34. Park H, Park J, Yu R. Relationship of obesity and visceral adiposity with serum concentrations of CRP, TNF-alpha and IL-6. Diabetes Res Clin Pract. 2005 Jul;69(1):29-35. http://dx.doi.org/10.1016/j.diabres.2004.11.007 PMID:15955385

35. Vogelzangs N, Suthers K, Ferrucci L, Simonsick E, Ble A, Schrager M, et al. Hypercortisolemic depression is associated with the metabolic syndrome in late-life. Psychoneuroendocrinology. 2007 Feb;32(2):151-9. https://doi.org/10.1016/j.psyneuen.2006.11.009

36. Morsink L, Vogelzangs N, Nicklas B, Beekman A, Satterfield S, Rubin S, et al. Associations between sex steroid hormone levels and depressive symptoms in elderly men and women: results from the Health ABC study. Psychoneuroendocrinology. 2007 Sep-Nov;32(8-10):874-83. http://dx.doi.org/10.1016/j.psyneuen.2007.06.009 PMID:17651906 